Krista Bērziña, $M g$. iur.

Latvijas Universitātes Juridiskās fakultātes doktorante, Latvija

\title{
KREDITORU INTEREŠU AIZSARDZĪBA UZN,ĒMUMA PĀREJAS GADĪJUMĀ
}

\section{PROTECTION OF CREDITORS' INTERESTS IN TRANSFER OF A BUSINESS}

\begin{abstract}
Summary
Within the scope of this article the author examines the understanding of transfer of a business within the meaning stipulated by Article 20 of the Latvian Commercial Law and criteria established in European and Latvian Court practice in order to prove that the transfer of business has occurred. In addition, the author analyses the issues regarding calculation of limitation period in transfer of business claims, as well as the subjects who could be held liable in case transfer of business has occurred. The article also contains analysis of Latvian case law findings regarding liability and limitation period.
\end{abstract}

Atslēgvārdi: uzņēmuma pāreja, kreditoru interešu aizsardzība, noilgums, atbildības nošķiršana, korporatīvā plīvura pacelšana

Keywords: transfer of business, protection of creditor interests, limitation period, separation of liability, piercing the corporate veil

\section{Ievads}

Raksta mērḳis ir izpētīt uzṇēmuma pārejas institūtu kā kreditoru interešu aizsardzības līdzekli, proti, kas ir uzṇēmuma pārejas prasība, kreditoru iespējas šo prasību celt, priekšnoteikumus, lai konstatētu uzñēmuma pārejas faktu, noilguma jautājumus saistībā ar šādas prasības celšanu un iespējamo atbildības subjektu loku.

Kā norādījis Komerclikuma projekta autoru grupas vadītājs Aigars Strupišs, nododot to Saeimas izskatīšanai un vispārējai iepazīšanai, trešo personu aizsardzības princips ir viens no komerctiesību stūrakmeņiem, minot kā piemēru trešo personu aizsardzības principa izpausmei arī uzṇēmuma pāreju. ${ }^{1}$

Komerclikuma 20. panta pirmās daḷas pirmais teikums nosaka - ja uzņēmums vai tā patstāvīga daḷa pāriet citas personas īpašumā vai lietošanā, uzṇēmuma ieguvējs atbild par visām uzṇēmuma vai tā patstāvīgās daļas saistībām. ${ }^{2}$ Šis pants arī imperatīvi paredz, ka vienošanās, kas ir pretēja šā panta noteikumiem, nav spēkā attiecībā uz trešajām personām.

\footnotetext{
1 Strupišs A. Par komerclikuma projektu, nododot to Saeimas izskatīšanai un vispārējai iepazīšanai. Pieejams: https://www.vestnesis.lv/ta/id/24539 [aplūkots 2019. gada 15. aprīlī].

2 Komerclikums. LV Likums. Latvijas Vēstnesis. 2000. 4. maijs, Nr. 158/160.
} 
Tādējādi sabiedrības kreditors (jeb persona, kurai uz saistību pamata ar sabiedrỉbu ir radušās prasijuma tiesības pret to) ir tiesīgs celt prasỉbu gan pret sabiedrïbu, pret kuru tam ir prasījums ("uznēēmuma nodevēju") (Komerclikuma 20. panta noteiktajā kārtībā un termiņā), gan pret citu sabiedrību, kurai nodots uzṇēmums ("uzṇēmuma ieguvēju”), un šie subjekti likumā paredzētajā kārtībā ir atbildīgi pret kreditoru.

Uzñēmuma pāreja ne vienmēr norit godprātīgi, kā piemēram var minēt sabiedrības (uzṇēmuma nodevēja) l̦aunprātīgu "iztukšošanu" un apzinātu novešanu līdz maksātnespējai nolūkā izvairīties no saistību izpildes pret sabiedrības (uzṇēmuma nodevēja) kreditoriem. Praksē ir gadījumi, kuros kreditors, ieguvis spriedumu pret parādnieku (uzñēmuma nodevēju), saprot, ka šo spriedumu nav iespējams izpildīt, jo sabiedrība ir "tukša" jeb visi tās aktîvi ir pārnesti jau uz citu sabiedrību (uzñēmuma ieguvēju), tādējādi faktiski uzṇēmums turpina darboties, bet jau ar citas juridiskās personas vārdu un šādā veidā izvairās no savu saistību izpildes pret kreditoriem. Kā norādīts arī Augstākās tiesas judikatūrā, uzṇēmuma pārejas institūta mērḳis ir novērst tās situācijas, kurās tiek "iztîrîti” komercsabiedrības aktīivi, neatstājot tās kreditoriem cerības sañemt tiem pienākošos samaksu. ${ }^{3}$

Šādos gadījumos talkā nāk Komerclikuma 20. pants, tomēr, lai to piemērotu, ir jāspēj pierādīt pazīmes, kas liecina par uzṇēmuma pāreju, tāpat ir jāpievēršas noilguma un atbildības subjektu jautājumam, kas tiks aplūkoti turpmāk šajā rakstā.

\section{Uzṇēmuma pārejas pazìmes}

Uzṇēmuma pārejas objekts ir pats uzṇēmums vai tā autonomā dą̧a. Uzṇēmuma jēdziens ir dots Komerclikuma 18. pantā, atbilstoši kuram uzṇēmums ir organizatoriski saimnieciska vienība. Uzņēmumā ietilpst komersantam piederošas ķermeniskas un bezķermeniskas lietas, kā arī citi saimnieciski labumi (vērtības), kurus komersants izmanto komercdarbības veikšanai. ${ }^{4}$

Uzṇēmumu pāreja tiek regulēta arī Darba likumā̄ ${ }^{5}$, kas no darba tiesisko attiecību aspekta papildina Komerclikumā lietoto jēdzienu, nosakot, ka uzṇēmuma pāreja šã likuma izpratnē ir uzṇēmuma vai tā patstāvīgas, identificējamas dą̧as (saimnieciskas vienības) nodošana citai personai uz līguma, administratīvā vai normatīivā akta, tiesas sprieduma vai kāda cita pamata, kas radies starp pusēm ārpus to līgumiskajām saistībām, kā arī komercsabiedrību apvienošana, sadalǐšana vai pārveidošana. ${ }^{6}$ Tomēr, tā kā Darba likums tikai papildina Komerclikumā lietoto jēdzienu, ir iespējams piemērot juridiskajā literatūrā un tiesu praksē norādītos skaidrojumus par uzṇēmumu pāreju darba tiesỉbu izpratnē arī attiecỉbā uz Komerclikuma 20. panta izpratnē esošo uzṇēmuma pāreju.

3 Latvijas Republikas Augstākās tiesas Civillietu departamenta 2017. gada 9. novembra spriedums lietā Nr. SKC-340/2017.

4 Komerclikums. LV Likums. Latvijas Vēstnesis. 2000. 4. maijs, Nr. 158/160.

5 Repšs A. Uzṇēmuma pāreja citai personai un darbinieku tiesību aizsardzība. Jurista Vārds. 2004. 9. marts, Nr. 9 (314).

6 Darba likums. LV Likums. Latvijas Vēstnesis. 2001. 6. jūlijs, Nr. 105. 
Kā atzìts tiesību doktrīnā, uzñēmuma pāreja jāklasificē pēc pārejas fakta un rezultāta, nevis pēc pārejas formas. ${ }^{7}$ Arī 2001. gada 12. marta Eiropas Padomes Direktīvā 2001/23/ $\mathrm{EK}^{8}$ par dalībvalstu tiesību aktu tuvināšanu attiecībā uz darbinieku tiesību aizsardzību uzn,ēmumu, uzn,ēmējsabiedrību vai uzn,ēmumu vai uzn,ēmējsabiedrību daļu īpašnieka maiņas gadījumā 1. panta b) punktā uzņēmuma pāreja tiek skaidrota kā ekonomiskas vienības pāreja, kā rezultātā tā saglabā savu identitāti. Minētais apstiprināts arī Eiropas Savienības un Latvijas tiesu praksē.

Eiropas Savienības Tiesa savos spriedumos ir skaidrojusi, ka par uzņēmuma pāreju liecina tas, ka uzņēmums ir saglabājis savu identitāti, ar to saprotot plašu tvērumu. Būtiski ir konstatēt, ka ir notikusi saimnieciskās struktūras pāreja. Saimnieciskās struktūras jēdzienu nevar sašaurināt līdz darbībai, kuru tā veic. Tās identitāti raksturo arī citi faktori, piemēram, tās personāls, vadība, veids, kādā tiek organizēts tās darbs, darba metodes vai pat attiecīgā gadījumā tai pieejamie līdzekḷi. ${ }^{9}$ Eiropas Savienības Tiesa savā praksē izškir vairākus kritērijus, ko var izmantot, noskaidrojot, vai organizatoriski saimnieciskā vienība saglabā savu identitāti. Šie kritēriji ir: 1) uzṇēmuma raksturs, 2) vai pārejas rezultātā tiek nodotas ķermeniskas lietas (ēkas, kustama manta), 3) kā arī uzñēmuma darbības līdzības raksturs pirms un pēc pārejas. ${ }^{10}$ Turklāt Eiropas Savienības Tiesa spriedumos ir atzinusi, ka uznēmuma pāreja ir tulkojama paplašināti, to izprotot ne tikai kā pāreju uz līguma pamata, bet arī uz administratīva vai normatīva akta pamata vai tiesas sprieduma pamata, kā arī pat gadījumos, kad līguma nav vispār. ${ }^{11}$ Savukārt Latvijas tiesu praksē tiesa secinājusi, ka, lai noskaidrotu, vai ir notikusi uzṇēmuma pāreja, ir jākonstatē, ka ir pārgājuši uzṇēmuma būtiskie elementi un ka ieguvējs var izmantot šo uzṇēmumu tā līdzšinējā veidā un profilā bez būtiskām izmaiñām. ${ }^{12}$ Ja ieguvējs var pēc būtības turpināt attiecīgo darbību ar uzṇēmumu, uzskatāms, ka uzṇēmums pārgājis, pat ja tā nenozīmīgas dal̦as palikušas atsavinātājam. ${ }^{13}$

Katram uzṇēmumam atškuiras tas, kas uzskatāms par tā būtiskajiem elementiem un kas pierāda tā identitāti. Tas ir atkarīgs no uzņēmuma komercdarbības veida un īpatnībām, tomēr tiesu praksē ir iezīmējušās atseviškłas pazìmes, kas ir kopējas un izplatītas uzṇēmuma pārejas gadījumos.

Kādā lietā tiesa ir atzinusi uzṇēmuma pārejas faktu, n,emot vērā to, ka uzṇēmums turpinājis sadarbību ar vieniem un tiem pašiem darijumu partneriem Eiropas

7 Strupišs A. Komerclikuma komentāri. a daḷa. Komercdarbības vispārīgie noteikumi (1.-73. pants). Riga: Aigara Strupiša juridiskais birojs, 2003, 115. lpp.

8 Eiropas Padomes Direktīva Nr. 2001/23/EK. Oficiālais Vēstnesis L 082, 22/03/2001 0016.-0020. lpp.

9 Eiropas Savienības Tiesas spriedums lietā Nr. C-175/99 Didier Mayeur v. Associtation Promotion de l'information messine. Sk. arī Eiropas Savienības Tiesas spriedumu lietā Nr. C-13/95 Süzen v. Zehnacker Gebäudereinigung.

10 Repšs A. Uzṇēmuma pāreja citai personai un darbinieku tiesību aizsardzība. Jurista Vārds. 2004. 9. marts, Nr. 9 (314).

11 Eiropas Savienības Tiesas apvienotās lietas C-171/94 un C-172/94 Merckx v. Ford Motor Company and Neuhuys [1996] ECR I-1253.

12 Latvijas Republikas Augstākās tiesas Civillietu tiesu palātas 2013. gada 5. novembra spriedums lietā Nr. C04367311, Latvijas Republikas Augstākās tiesas Senāta 2007. gada 14. marta spriedums lietā Nr. SKC-134.

13 Strupišs A. Komerclikuma komentāri. a daḷa. Komercdarbības vispārīgie noteikumi (1.-73. pants), Aigara Strupiša juridiskais birojs, 2003, 115. lpp. 
Savienības dalībvalstīs, turklāt trīs no sešiem uzñēmuma darbiniekiem turpinājuši strādāt jaunajā sabiedrībā un bijuši vienīgie sabiedrības darbinieki. Tiesa secināja, ka ir notikusi visa uzṇēmuma vai tā daļas mantas kopības pāreja, turklāt aktīvu kopums nodrošinājis to, ka jaunā sabiedrība bija spējīga ar saņemtajiem aktīviem nodrošināt atsevišķa komercdarbības veida patstāvīgu funkcionēšanu, par ko liecinājis tas, ka tā turpināja iepriekšējās sabiedrības veikto komercdarbỉbas veidu, turpinot sadarbỉbu ar piegādātājiem un pakalpojumu sniedzējiem. ${ }^{14}$

Attīstot uzṇēmumu pārejas pazīmes, Latvijas Republikas Augstākās tiesas Senāts norādījis, ka par uzṇēmumu pāreju var liecināt šādu konkrētu apstākḷu kopums: darbinieku pāriešana darbā pie ieguvēja, pamatlīdzekḷu un krājumu nodošana, saglabāta uzņēmuma atrašanās vieta un juridiskā adrese, saistību pret banku pārn,emšana, atsavinātājas sabiedrības valdes locekḷa pāriešana pie ieguvēja. ${ }^{15}$

Viena no pamatlietām Eiropas Savienības Tiesas praksē, kurā tika minētas pazīmes, kas jāvērtē, lai konstatētu uzñēmuma pārejas faktu, ir Spijkers lieta ${ }^{16}$, kurā tiesa norādījusi, ka ir svarīgi vērtēt šādus faktorus: 1) uzṇēmuma komercdarbības veids; 2) uzñēmuma ķermenisku lietu, tādu kā ēku un kustamu lietu, un bezķermenisku lietu pāreja; 3) bezķermenisko aktīvu vērtība uzṇēmuma pārejas brīdī; 4) vairākuma uzṇēmumā nodarbināto darbinieku pārṇemšana; 5) uzṇēmuma klientu pārṇemšana; 6) darbību līdzības raksturs pirms un pēc uzṇēmuma pārejas. Identitātes pāreja izriet arī no citiem faktoriem, tādiem kā darbaspēks, vadība, veids, kādā darbs tiek organizēts, metodes, ko izmanto uzṇēmums u. c. ${ }^{17}$ Minētie kritēriji tikuši izvērtēti arī virknē citu Eiropas Savienības Tiesas lietu. ${ }^{18}$

Tātad, lai konstatētu uzñēmuma pārejas faktu, ir jāspēj pierādīt, ka: 1) uzn̄ēmuma būtiskās daḷas ir pārgājušas jaunajam ieguvējam un 2) uzṇēmums ir saglabājis savu identitāti. Pazīmes, kas varētu liecināt par uzṇēmuma pāreju, ir, piemēram, 1) komercdarbības veikšanas vieta (t. sk. juridiskā adrese) un 2) veids, 3) uzṇēmuma inventārs, 4) darbinieki, 5) naudas līdzekḷu plūsma, 6) vadība, 7) uzṇēmuma darbỉbas līdzības raksturs, 8) klientūra, 9) saistību pret banku pārn̦emšana u. c. būtiskas pazīmes, kas liecina par uzṇēmuma identitātes pārņemšanu (preču zīmes, mājaslapa, publiskā informācija u. c.). Jebkurā gadījumā šìs pazīmes nav izsmel̦ošas, un galvenā pazìme ir

14 Latvijas Republikas Administratīvā rajona tiesas 2013. gada 27. augusta spriedums lietā Nr. A420509512.

15 Latvijas Republikas Augstākās tiesas Civillietu departamenta 2017. gada 9. novembra spriedums lietā Nr. SKC-340/2017.

16 Eiropas Savienības Tiesas 1986. gada 18. marta spriedums lietā Nr. 24/85 Jozef Maria Antonius Spijkers $v$ Gebroeders Benedik Abattoir CV and Alfred Benedik en Zonen BV.

17 Barnard C. EU Employment law. Fourth Edition. Oxford University Press, 2012, p. 596.

18 Sk., piemēram, Eiropas Savienības Tiesas 1986. gada 18. marta spriedumu lietā 24/85 Jozef Maria Antonius Spijkers $v$ Gebroeders Benedik Abattoir CV et Alfred Benedidik en Zonen BV, para 13; Eiropas Savienības Tiesas 1988. gada 15. jūnija spriedumu lietā 101/97 Bork International A/S, in liquidation $v$ Foreningen of Arbejdsledere I Danmark, acting on behalf of Birger E. Petersen, ECR, 1988, p. 3057; Eiropas Savienības Tiesas 1992. gada 19. maija spriedumu lietā C-29/91 Dr. Sophie Redmond Stichting $v$ Hendrikus Bartol and others, ECR 1992, p. I-3189; Eiropas Savienibas Tiesas 1992. gada 16. decembra spriedumu apvienotajās lietās C-132/91, C-138/91 un C-139/91 Grigorios Katsikas v Angelos Konstantidis and Uwe Skreb and Günter Schroll v PCO Stauereibetrieb Paetz \& Co Nachfolger GmbH, paras 33, 34, 35 u. c. 
un paliek tā, vai uzņēmums pēc būtības turpina savu darbību līdzšinējā formā un vai uzṇēmuma būtiskie elementi ir pārgājuši, kas ir katrā konkrētā gadījumā atkarīgs no uzñēmuma komercdarbības veida un īpatnībām. Konstatējot to, ir pamats atzìt, ka ir notikusi uzṇēmuma pāreja un jaunais uzṇēmuma ieguvējs ir atbildīgs par uzņēmuma nodevēja saistībām pret kreditoriem, kā to nosaka Komerclikuma 20. pants.

\section{Noilguma problēmjautājumi uzṇēmuma pārejas gadījumā}

Uzñēmuma pārejas pazīmju konstatēšanas gadỉjumā pirms prasības celšanas tiesā ir būtiski konstatēt, vai prasībai nav iestājies noilgums. Saskaṇā ar Civillikuma ${ }^{19}$ 1893. pantu saistību tiesības beidzas, ja tiesīgā persona tās pienācīgi neizlieto likumā noteiktā noilguma termiņā.

Komerclikuma 20. panta pirmās daļas otrajā teikumā ir atsauce uz piecu gadu aizsardzības noilguma terminu, tomēr tas attiecas uz uzṇēmuma nodevēja un ieguvēja solidāro atbildību. Tomēr, lai kreditors varētu īstenot savu prasījumu, kas izriet no saistības, kura noslēgta ar uzṇēmuma nodevēju, tā jāīsteno likumā noteiktajā termiṇā. Tā kā saistības viena puse ir komersants (uzņēmuma nodevējs), visticamāk, šis pamats varētu būt komercdarījums. Tādā gadijjumā noilguma aprēķināšanai piemērojams Komerclikuma 406. pantā ietvertais speciālais trīs gadu termiņš, kas piemērojams kopsakarā ar Komerclikuma Pārejas noteikumu 16. punktu, skaitot šo termiṇu no 2010. gada 1. janvāra. ${ }^{20}$

Noilgumu ir iespējams pārtraukt, atgādinot parādniekam par saistības izpildi, celıot prasību tiesā, vai ja parādnieks atzinis kaut kādā kārtā kreditora prasību (Civillikuma 1902.-1906. pants). Augstākā tiesa savā praksē ir nostiprinājusi atziṇu, ka Komerclikuma 406. pantā noteiktā speciālā noilguma termiņa pārtraukšanas no jauna skaitāms tas pats Komerclikuma trīs gadu noilguma termiņš, nevis Civillikumā paredzētais vispārējais noilguma termiņš. ${ }^{21}$ Tiesa pamatojusi šādu uzskatu ar apstākli, ka tas sekmē tiesisko noteiktību un ātrumu komerctiesiskajā apgrozībā, kā arī ir atbilstošs komerctiesību principiem, īpaši privāttiesiskās apgrozības paātrināšanas principam (komersantam operatīvi jāreagé uz apstākḷ izmaiņām, proti, prasījumi savu tiesību aizsardzībai jāiesniedz pietiekami ātri). ${ }^{22}$

Cel̦ot prasību par saistību izpildi, kreditors pārtrauc noilguma tecējumu. Iegūstot nolēmumu un izpildu rakstu par šo nolēmumu pret parādnieku (uzñēmuma nodevēju), atbilstoši Civilprocesa likuma 546. pantam $^{23}$ kreditors iegūst tiesības to iesniegt piespiedu izpildei 10 gadu laikā no tiesas vai tiesneša nolēmuma spēkā stāšanās dienas, ja likumā nav noteikti citi noilguma termiṇi. Tātad, ja pret parādnieku (uzṇēmuma

19 Civillikums. LV Likums. Valdības Vēstnesis. 1937. 20. februāris, Nr. 41.

20 No komercdarījuma izrietošie prasījumi noilgst triju gadu laikā, ja likumā nav noteikts cits noilguma termiņš.

21 Latvijas Republikas Augstākā tiesas Civillietu departamenta 2017. gada 14. decembra lietā Nr. SKC$265 / 2017$.

22 Turpat.

23 Civilprocesa likums. LV Likums. Latvijas Vēstnesis. 1998. 3. novembris, Nr. 326/330. 
nodevēju) ir spēkā esošs nolēmums, uz to attiecināms 10 gadu noilguma termiņa tecējums. Faktiski strīda par saistības pastāvēšanas faktu vairs nav, bet atbilstoši Komerclikuma 20. pantam mainās subjekts, kas ir atbildīgs par šīs saistības izpildi, tāpēc pret uzn̦ēmuma ieguvēju būtu cel̦ama atsevišksa prasība pēc Komerclikuma 20. panta, pierādot uzñēmuma pārejas faktu.

Saskaņā ar Civillikuma 1905. un 1906. pantu ir pamats uzskatīt, ka noilgums pārtrauc savu tecējumu arī tā iemesla dẹl, ka maksātnespējas procesā kreditors ir pieteicis savu prasījumu un ir atzīts par kreditoru (t. i., parādnieks ir atzinis prasību). Tomēr, kas notiek, ja kreditors nav pieteicis savu prasījumu parādnieka (uzṇēmuma nodevēja) maksātnespējas procesā? Salīdzinoši nesen Latvijas Republikas Augstākās tiesas Civillietu departaments skatīja jautājumu par to, vai, nepiesakot kreditora prasījumu parādnieka (uzṇēmuma nodevēja) maksātnespējas procesā, prasītāja zaudē prasījuma tiesības arī pret atbildētāju (uzṇēmuma ieguvēju) un uzņēmuma pārejas fakta atzīšana tādējādi nerada prasītājai (kreditoram) mantiskas tiesības. ${ }^{24}$ Konkrētajā lietā prasītājam bija pozitīvs tiesas spriedums pret parādnieku (uzṇēmuma nodevēju), bet, pasludinot parādnieka (uzṇēmuma nodevēja) maksātnespējas procesu, prasītājs nebija pieteicis savu kreditora prasījumu. Attiecīgi parādnieka (uzṇēmuma nodevēja) maksātnespējas process tika pabeigts, un šì sabiedrība tika izslēgta no komercreǵistra. Apelācijas instances tiesa atteicās nodibināt uzñēmuma pārejas faktu, norādot, ka prasītāja ir zaudējusi prasījuma tiesības gan pret parādnieku (uzṇēmuma nodevēju), gan pret atbildētāju (uzñēmuma ieguvēju), jo nav pieteikusi kreditora prasījumu parādnieka (uzn̄ēmuma nodevēja) maksātnespējas procesā. Tomēr kasācijas instances tiesa nepiekrita šim secinājumam un norādīja, ka atbilstoši Civillikuma 1402. pantam saistības, kas rodas no uzṇēmuma pārejas, nodibinās uz likuma pamata ar brīdi, kad tiek konstatēta uzṇēmuma pāreja. Ja tiesa nodibinājusi uzṇēmuma pārejas faktu, prasītājai ir radušās prasījuma tiesības arī pret uzn,ēmuma ieguvēju, un kreditora prasījuma nepieteikšana vēlāk maksātnespējas procesā nevar ietekmēt jau iegūtās prasijuma tiesības pret parādnieku (uzṇēmuma nodevēju). Atbildētājas (uzṇēmuma ieguvēja) saistība nevar automātiski izbeigties tāpēc, ka vienas solidāri saistītās personas (uzṇēmuma nodevēja) saistība tiek izbeigta. Šāds secinājums ir logisks un pamatots, proti, uzṇēmuma pārejas pamatā ir solidāra saistība, tādējādi, ja kreditors jau ir ieguvis pozitīvu spriedumu pret parādnieku (uzṇēmuma nodevēju), saistība ir tikusi nodibināta un, lai gan kreditors nav pieteicis kreditora prasījumu parādnieka (uzṇēmuma nodevēja) maksātnespējas procesā (tādējādi uzṇēmuma nodevēja saistība pret kreditoru ir izbeigusies), taču tas neizbeidz uzñēmuma ieguvēja saistību pret kreditoru.

Vienlaikus jāvērš uzmanība, ka, ja saistībai nav iestājies termiņš, bet uzṇēmuma nodevējam tiek pasludināta maksātnespēja, kreditoram būtu jāpiesaka savs kreditora prasījums maksātnespējas administratoram, jo atbilstoši Maksātnespējas likuma ${ }^{25}$ 63. panta trešajai daḷai, pēc maksātnespējas pasludināšanas visām parādnieka saistībām iestājas izpildes termiņšs. Savukārt šĩ likuma 73. panta otrā daḷa nosaka, ka, ja kreditors nepiesaka savu prasījumu sešu mēnešu laikā no dienas, kad maksātnespējas reǵistrā

24 Latvijas Republikas Augstākās tiesas Civillietu departamenta 2017. gada 15. decembra spriedums lietā Nr. SKC-330/2017.

25 Maksātnespējas likums. LV Likums. Latvijas Vēstnesis. 2010. 6. augusts, Nr. 124. 
izdarīts ieraksts par parādnieka maksātnespējas procesa pasludināšanu, iestājas noilgums, un kreditors zaudē kreditora statusu un savas prasijuma tiesības pret parādnieku, tādējādi zaudējot savas prasījuma tiesības arī pret uzṇēmuma ieguvēju.

Ja kreditors ir veicis darbības, lai realizētu savas prasījuma tiesības pret uzṇēmuma nodevēju, taču tās nav izdevies realizēt pilnīgi, jo uzṇēmuma nodevējam nav pietiekami aktīvu, tad, ja kreditors ir informēts par to, ka ir notikusi uzṇēmuma pāreja, logiska kreditora turpmākā rīcība būtu prasības celšana pret uzṇēmuma ieguvēju. Tomēr l̦aunprātīgas uzṇēmuma pārejas gadījumā, t. i., tādas, ar kuru parādnieks cenšas apiet kreditora intereses, kreditors par uzṇēmuma pārejas faktu var uzzināt vien pēc vairākiem gadiem, piemēram, pētot uzñēmuma komercdarbības gaitu, iespējams, ierodoties komercdarbības veikšanas vietā, līdz ar to kreditora iespējas uzzināt, vai un kura komercsabiedrība pārṇēmusi uzṇēmumu, ir apgrūtināta un atkarīga no tā, kāds ir šis uzņēmums un ar ko tas nodarbojas. Dažos gadijjumos var būt l̦oti vienkārši noslēpt uzñēmuma pāreju, un tā var atklāties pavisam nejauši, pēc kāda laika kreditoram saskaroties ar faktu, ka, saglabājis tā identitāti, uzṇēmums faktiski funkcionē tālāk. Tādējādi kreditoram vienmēr jābūt īpaši vērīgam un uzmanīgi jāseko līdzi tam, kur parādnieka aktīvi ir tikuši novirzīti (piemēram, parādniekam piederošie nekustamie īpašumi, ja tas ir saistīts ar parādnieka komercdarbību), vai parādnieka komercdarbība tiek turpināta, kas darbojas parādnieka juridiskajā adresē, kam pieder parādnieka preču zīmes, uzmanīgi jāpēta parādnieka gada pārskati, sekojot, piemēram, aktīvu plūsmai u. c. būtiskiem aspektiem, lai konstatētu, vai ir notikusi uzṇēmuma pāreja.

Augstākā tiesa atzinusi, ka saistības, kas rodas no uzñēmuma pārejas, nodibinās uz likuma pamata ar brīdi, kad tiek konstatēta uzṇēmuma pāreja. ${ }^{26}$ Civillikuma 1895. pantā paredzētais desmit gadu noilguma termiņš attiecas uz ikvienu saistību tiesību neatkarīgi no saistību rašanās pamata, vienlaikus Komerclikuma 406. pants paredz saīsināto trīs gadu noilguma termiņu. Asociētais profesors Jānis Kārkliņš uzsvēris - lai uz kāda pamata būtu radies prasījums, Komerclikuma 406. panta tvērums attiecas uz ikvienu prasījumu, kurš izriet no komerctiesiskās aprites jeb, citiem vārdiem, ir komerctiesiskas dabas. ${ }^{27}$ To apstiprinājis arī Latvijas Republikas Augstākās tiesas Senāts pavisam nesenā spriedumā 2019. gada 30. maijā lietā SKC-104/2019, secinot, ka tam, vai saistība rodas uz likuma vai darījuma pamata, nav juridiskas nozīmes, lai vērtētu, vai prasījumam ir piemērojams Komerclikuma 406. panta regulējums. Būtiskais elements ir tas, vai komersanta prasijums ir komerctiesiskas dabas. Ja prasijums ir komerctiesiskas dabas, nav pamata piemērot desmit gadu noilguma terminuu. ${ }^{28}$ Šādam secinājumam it kā varētu piekrist, jo tieši tāds ir Komerclikumā noteiktā noilguma termiņa mērķis, proti, sekmēt tiesisko noteiktību un ātrumu komerctiesiskajā apgrozībā, tomēr neatbildēts paliek jautājums, kad sāk tecēt noilguma termiṇš prasības celšanai pret uzṇēmuma ieguvēju vai kā ir iespējams noteikt uzṇēmuma pārejas konstatēšanas brīdi.

26 Latvijas Republikas Augstākās tiesas Civillietu departamenta 2017. gada 15. decembra spriedums lietā Nr. SKC330/2017.

27 Kārklinš̌ J. Noilgums piespiedu nomas attiecībās komerctiesībās. Centrālās un Austrumeiropas juridiskās tradīcijas un juridiskās identitātes jautājumi. Latvijas Universitātes 76. starptautiskās zinātniskās konferences rakstu krājums. Rīga: LU Akadēmiskais apgāds, 2018, 39. lpp.

28 Latvijas Republikas Augstākās tiesas Senāta 2019. gada 30. maija spriedums lietā Nr. SKC-104/2019. 
Doktrīnā noteikts, ka, ja likumā nav noteikts cits noilguma tecējuma sākuma termiņš, ievēro principu, ka noilgums sāk tecēt ar brīdi, kad kreditors uzzinājis vai viṇam vajadzēja uzzināt par tiesību pārkāpumu. ${ }^{29}$ Šāda atziṇa apstiprināta arī pavisam nesenā Augstākās tiesas praksēe ${ }^{30}$ Izvērtējot noilguma termiṇa tecējuma sākumu, būtu katrā konkrētā gadījumā jāṇem vērā šādi apstākḷi: kad iestājusies saistība, uz kuras pamata kreditoram radies prasījums pret uzņēmuma nodevēju, vai kreditors ir veicis kādas aktīvas darbības savas saistības realizācijai - pieteicis savu prasījumu maksātnespējas administratoram, realizējis savu prasījumu pret uzn,ēmuma nodevēju, iegūstot spriedumu utt., kā arī to, cik acīmredzami ir konstatējama uzņēmuma pāreja (piemēram, vai to ir iespējams noteikt, kreditoram izpētot parādnieka (uzn,ēmuma nodevēja) gada pārskatu, ņemot vērā arī apstākli, vai parādniekam (uzṇēmuma nodevējam) gada pārskati vispār ir iesniegti un publiski pieejami), kāds ir parādnieka komercdarbības veids, proti, vai uzṇēmuma pāreja ir viegli identificējama u. c. būtiski apstākḷi.

\section{Atbildības subjekti uzṇēmuma pārejas gadỉjumā}

Komerclikuma 20. pants nosaka uzṇēmuma nodevēja un ieguvēja solidāru atbildību par saistībām, kuras radušās pirms uzṇēmuma pārejas un kuru izpildes termiņš vai nosacījums iestājies piecu gadu laikā pēc uzņēmuma pārejas. Tomēr šis pants tikai paredz gadỉjumu, kurā piemērojama solidāra atbildība, nevis nosaka visus atbildīgos subjektus uzṇēmuma pārejas gadījumā. Kā jau minēts raksta sākumā, uzṇēmuma pāreja praksē bieži notiek tieši negodprātīgu motīvu dēl - lai izvairītos no saistību izpildes pret kreditoru, bet faktiski turpinātu komercdarbibu jau ar citas juridiskas personas starpniecību - atstājot uzṇēmuma nodevēju "iztukšotu” un kreditorus ar garu degunu.

Aiz katras juridiskas personas ir fiziska persona, kas rīkojas šīs juridiskās personas vārdā, bet faktiski savu interešu vadīta. Pati juridiskā persona nespēj ne slēgt darījumus, ne sniegt pakalpojumus, ne ražot preces. Šim nolūkam ir nepieciešamas fiziskās personas, kuras šo rīcībspēju realizê. ${ }^{31}$ Lìdz ar to ir skaidrs, ka visos gadỉjumos, kad kāda kapitālsabiedrība ir iesaistīta jebkādos tiesiskos, šlরietami tiesiskos vai prettiesiskos darījumos, tas ir noticis vai nu tās pārvaldes institūciju locekḷu, vai dalībnieku individuālas, vai arī viņu visu saskaņotas rīcības rezultātā un viṇu interešu vadītas. ${ }^{32}$ Tādos gadījumos tiek secināts, ka juridiska persona, kuras atbildība ir formāli nodalīta, tiek izmantota komerctiesiskajā apritē kā speciāls veidojums, lai konkrētās sabiedrības dalībnieki vai citas personas, kas to kontrolē, iegūtu no tās labumu.

Komerclikuma 137. panta trešā daļa paredz, ka dalībnieks neatbild par sabiedrības saistībām, nodibinot tā saucamo korporatīvo plīvuru starp sabiedrību kā juridisku personu (fikciju) un fiziskajām personām, kas veido šo juridisko personu. Tas ir

29 Latvijas Republikas Civillikuma komentāri: Ceturtā daļa. Saistību tiesības. K. Torgāns (zin. red.). Rìga: Mans ipašums, 1998, 360.-361. lpp.

30 Latvijas Republikas Augstākās tiesas Senāta 2019. gada 24. aprīla spriedums lietā Nr. SKC-46/2019.

31 Strupišs A. Tiesas spriedumu komentāri: par valdes locekli kā darbinieku. Jurista Vārds, 2012. 28. februāris, Nr. 9 (708).

32 Alliks A. Korporatīvā plīvura pacelšanas krimināltiesiskie aspekti. Jurista Vārds, 2013. 9. jūlijs, Nr. 27/28. 
fundamentāls princips ne vien Latvijā, bet arī citviet pasaulē. ${ }^{33}$ Mērḳis šāda korporatīva plīvura radīšanai ir veicināt komerctiesisko darïjumu apriti, komercdarbības ātrumu un efektivitāti, lai fiziskām personām nebūtu jābaidās no ikkatras komerciālas neveiksmes, kas varētu radīt mantiskas sekas. Tomēr šì panta mērkisis nav un nevar būt aizsegs dalībniekiem apzinātu darbību veikšanai, kas rada zaudējumus kreditoriem, piemēram, sabiedrības apzināta iztukšošana, pārnesot aktīvus citai sabiedrībai, kas nereti praksē nozīmē tās novešanu līdz maksātnespējai (kas ir Krimināllikuma 213. pantā paredzēts noziedzīgs nodarījums).

Svarīgi ir novilkt robežu starp komerciālu neveiksmi un apzinātu personas rīcību, kas ir vērsta uz radušos apstākḷu izmantošanu savā labā, aizskarot patērētāju, kreditoru, valsts vai pašvaldỉbu intereses. ${ }^{34}$ Lìdzìgs uzskats pastāv arī korporatīvā plìvura pacelšanas teorijā (piercing of corporate veil), ka, ja juridiska persona kā veidojums tiek izmantota, lai grautu sabiedrisko kārtību, attaisnotu neattaisnojamu rīcību, aizsargātu krāpšanu vai noziegumu, tas ir pamats, lai paceltu korporatīvo plīvuru. Amerikāņu profesors Henrijs Balentains (Ballantine) norādījis: "Tas ir jautājums par labu ticību un godīgumu, izmantojot korporatīvās privilēgijas likumīgiem mērḳiem." ${ }^{35}$

Tiesu praksē pastāv dažādi un, pat varētu teikt, diametrāli pretēji viedokḷi par šo jautājumu. Tā, piemēram, Latvijas Republikas Augstākās tiesas Civillietu departaments 2017. gada 9. novembra spriedumā lietā Nr. SKC-340/20176, skatot jautājumu par uzṇēmuma pārejas tvērumu un atbildību tajā, norādījis, ka Komerclikuma 20. pantā noteiktā atbildība attiecas tikai uz uzṇēmuma nodevēja un ieguvēja atbildību, tādējādi aprobežojot jebkādu citu subjektu iespējamo atbildību, pamatojoties uz šo pantu. Vienlaikus tiesa norādījusi, ka uzṇēmuma nodevēja valdes loceklim atbildība uz minētā panta pamata neiestājas.

Šajā lietā apelācijas instances tiesa apmierināja maksātnespējas procesa administratora prasību, pamatojoties uz Komerclikuma 20. pantu un 169. pantu, tomēr Augstākā tiesa atzina, ka tiesa esot kḷūdaini piemērojusi no uzṇēmuma pārejas regulējuma izrietošo solidārās atbildības principu, jo neesot nošķ̄īusi uzṇēmuma pārejas procesā iesaistītās personas - komersantus (uzņēmuma nodevēju un uzṇēmuma ieguvēju) - no kapitālsabiedrības izpildinstitūcijas - valdes, kas pārstāv un vada sabiedrību. Tā kā komersants esot speciālais komerctiesību subjekts (komercregistrā ierakstīta fiziskā vai juridiskā persona - individuālais komersants vai komercsabiedrība), un tikai komersanta veiktā darbība uzskatāma par komercdarbību, tad attiecīgi Augstākā tiesa secinājusi, ka valdes loceklis nebūtu līdzatbildīgs. Komerclikuma 20. pants un 169. pants regulējot pilnīgi atškirīgus atbildības iestāšanās pamatus, kas izslēdz atbildētāju (uzṇēmuma ieguvējas un bijušā valdes locekḷa) solidāru atbildỉbu.

33 Thompson R. B. Piercing the Corporate Veil: An Empirical Study. Cornell Law Review. Volume 76, 1991, 5 July, p. 1039.

34 Bērziņš J. Maksātnespējas procesa krimināltiesiskie aspekti. Jurista Vārds, 09.10.2007., Nr. 41.

35 Ballantine H. W. Separate Entity of Parent and Subsidiary Corporations. California Law Review, Vol. 14, November, 1925, p. 19.

36 Latvijas Republikas Augstākās tiesas Civillietu departamenta 2017. gada 9. novembra spriedums lietā Nr. SKC-340/2017. 
Jāpiekrīt Augstākās tiesas secinājumam, ka Komerclikuma 20. pants un 169. pants regulē dažādus atbildības pamatus, kas nav jaucami kopā, un prasība, iespējams, nebija konstruēta pamatoti. Tomēr, pēc autores domām, tiesa spriedumā ir pārāk šauri izdarījusi secinājumu par atbildības subjektu loku uzñēmumu pārejas gadījumā. Būtisks aspekts, kas jānemem vērā, analizējot šo lietu, ir, ka konkrētajā gadījumā sabiedrības jeb uzṇēmuma nodevēja valdes loceklis bija arī sabiedrỉbas vienīgais dalïbnieks, kas attiecīgajā situācijā veica uzṇēmuma aktīvu nodošanu uzṇēmuma ieguvējam - citai sabiedrībai (kuras vienīgais valdes loceklis un dalībnieks bija atbildētāja laulātā), lai apietu kreditoru intereses un izvairītos no saistību izpildes. Tātad darbïba, ko veica valdes loceklis (dalïbnieks), bija apzināta un negodprātīga, kas vērsta uz trešo personu interešu aizskaršanu, kura savukārt ir pretēja Civillikuma 1. pantā nostiprinātajam labas ticības principam. Laba ticība doktrīnā tiek traktēta kā pienākums ievērot un respektēt citu personu pamatotās intereses. ${ }^{37}$

Autore uzskata, ka it sevišķi gadijjumos, kad valdes loceklis ir bijis arī vienīgais sabiedrības dalībnieks un notikusi uzṇēmuma pāreja ar mērķi apiet kreditora intereses, kas, protams, notikusi, ši dalībnieka interešu vadìta, būtu pamats izvērtēt šīs personas līdzatbildību. Turklāt praksē autore ir saskārusies ar gadijumiem, kad, pat cel̦ot uzñēmuma pārejas prasību pret uzñēmuma ieguvēju, tas vienlaikus jau "pārnesis" uzñēmumu atkal jaunam ieguvējam, šādā veidā faktiski liekot kreditoram skriet pakal negodprātīgajam parādniekam, kas nebūtu samērīgi. Augstākās tiesas Civillietu departaments 2017. gada 15. jūnija spriedumā SKC-108/2017 ${ }^{38}$ pamatoti norādīiis: "Tiesiskā valstī nevar tikt akceptēta situācija, ka juridiskas personas aizsegā fiziska persona apzināti veic prettiesiskas darbības, neuzṇemoties atbildību par trešajām personām nodarītajiem zaudējumiem." ${ }^{39}$ Svarīgs kritērijs, izvērtējot atbildības jautājumu un iespējamo korporatĩvā plīvura pacelšanas jautājumu, ir, vai personas rīcība ir samērojama ar pretējās puses interesēm un ir akceptējama no tiesiskuma viedokḷa. Iespējamais prasījuma pamats šādām prasībām varētu būt arī Koncernu likums. Koncerna likuma 1. panta 8. punkts paredz, ka uzñēmums ir ne vien komercsabiedrība Komerclikuma izpratnē, bet arī fiziska persona. Turklāt Koncernu likums uzsver arī kreditoru aizsardzības prioritāti (Koncernu likuma 2. panta ceturtā daļa).

Līdz ar to ir secināms - ja sabiedrības akcionāri vai dalībnieki ignorē un aizskar kreditoru intereses, apzināti pien̦emot lēmumus un rỉkojoties ar uzṇēmuma mantu kā savu, tādā veidā radot zaudējumus trešajām personām, būtu izvērtējama šāda rīcība, un, konstatējot personas apzinātu neattaisnojamu rīcību ar mērḳi izvairīties no saistỉbu izpildes pret kreditoriem, būtu jāsecina, ka ši persona ir līdzatbildīga.

37 Balodis K. Labas ticības princips mūsdienu Latvijas civiltiesībās. Jurista Vārds, 03.12.2002. Nr. 24.

38 Latvijas Republikas Augstākās tiesas Civillietu departamenta 2017. gada 15. jūnija spriedums lietā Nr. SKC-108/2017.

39 Ibid. 


\section{Kopsavilkums}

1. Trešo personu aizsardzības princips ir viens no Komerclikuma pamatprincipiem, lìdz ar to uzņēmumu pārejas institūts, kas regulēts Komerclikuma 20. pantā, ir viens no trešo personu aizsardzības principa izpausmēm. Uzṇēmuma pārejas mērḳis ir novērst situācijas, kurās tiek "iztīrīti” sabiedrības aktīvi, neatstājot tās kreditoriem cerības saṇemt tiem pienākošos samaksu. Kā atzìts tiesību doktrīnā un tiesu praksē, uzn,ēmuma pāreja jāklasificē pēc pārejas fakta un rezultāta, nevis pēc pārejas formas, turklāt uzñēmuma pāreja var notikt ne tikai uz līguma pamata, bet arī gadijumos, kad līguma vispār nav. Tādējādi trešajai personai (kreditoram) ir iespēja celt uzṇēmuma pārejas prasību, pamatojoties uz Komerclikuma 20. pantu, ja ir iespējams pierādīt, ka uzṇēmuma būtiskie elementi ir pārgājuši un uzṇēmums ir saglabājis savu identitāti.

2. Komerclikuma 20. pants neparedz noilguma termiņu prasības celšanai pret uzñēmuma ieguvēju. Ši panta pirmās daļas otrajā teikumā ir tikai atsauce uz piecu gadu aizsardzības noilguma terminu, tomēr tas attiecināms tikai uz uzṇēmuma nodevēja un ieguvēja solidāro atbildību. Dažos gadijumos var būt l̦oti vienkārši noslēpt uzṇēmuma pāreju, un tas kreditoram var atklāties pavisam nejauši, pēc kāda laika saskaroties ar faktu, ka, uzṇēmums, saglabājot tā identitāti, patiesībā turpina funkcionēt. Tādējādi kreditoram vienmēr jābūt īpaši vērīgam un uzmanīgam, kā arī rūpīgi jāseko līdzi saistības izpildes terminiem un parādnieka komercdarbībai un finansiālajam stāvoklim, n,emot vērā to, ka pastāv vairāki noilguma termiṇi - gan Komerclikumā noteiktais trīs un piecu gadu noilguma termiņš̌, gan Maksātnespējas likumā noteiktais sešu mēnešu noilguma termiňš, gan Civillikumā noteiktais desmit gadu noilguma termiņš, kurus palaižot garām var zaudēt iespēju celt prasību pēc Komerclikuma 20. panta.

3. Komerclikuma 137. panta trešã daḷa nostiprina tā saucamo korporatīvo plīvuru, nosakot, ka dalībnieks neatbild par sabiedrības saistībām. Mērḳis šāda korporatīva plīvura radīšanai ir bijis veicināt komerctiesisko darījumu apriti, komercdarbības ātrumu un efektivitāti, lai fiziskām personām nebūtu jābaidās no ikkatras komerciālas neveiksmes, kas varētu radīt mantiskas sekas. Tomēr šì panta mērķis nav un nevar būt aizsegs dalībniekiem apzinātu darbību veikšanai, kas rada zaudējumus kreditoriem. Tiesiskā valstī nevar tikt akceptēta situācija, ka juridiskas personas aizsegā fiziska persona apzināti veic prettiesiskas darbības, neuzṇemoties atbildību par trešajām personām nodarītajiem zaudējumiem. Svarīgs kritērijs, izvērtējot atbildības jautājumu un iespējamo korporatīvā plīvura pacelšanas jautājumu, ir, vai personas rīcība ir samērojama ar pretējās puses interesēm un ir akceptējama no tiesiskuma viedokl̦a. Lìdz ar to būtu izvērtējama uzn,ēmuma dalībnieku atbildỉba uzṇēmuma pārejas gadījumā, ja uzṇēmuma pāreja notikusi negodprātīgu motīvu dēl, proti, lai izvairītos no saistību izpildes pret kreditoriem un turpinātu komercdarbỉbu jau ar citas juridiskas personas starpniecību. 


\section{BIBLIOGRĀFIJA}

\section{Literatūra}

1. Alliks A. Korporatīvā plīvura pacelšanas krimināltiesiskie aspekti. Jurista Vārds, 2013. 9. jūlijs, Nr. 27/28.

2. Ballantine W. H. Separate Entity of Parent and Subsidiary Corporations. In: 14 California Law Review, 1925 November, pp. 12-21.

3. Balodis K. Labas ticības princips mūsdienu Latvijas civiltiesībās. Jurista Vārds, 03.12.2002., Nr. 24.

4. Barnard C. EU Employment law. Fourth Edition. Oxford University Press, 2012.

5. Bērziņš J. Maksātnespējas procesa krimināltiesiskie aspekti. Jurista Vārds, 09.10.2007., Nr. 41.

6. Kārkliņš J. Noilgums piespiedu nomas attiecībās komerctiesībās. Centrālās un Austrumeiropas juridiskās tradīcijas un juridiskās identitātes jautājumi. Latvijas Universitātes 76. starptautiskās zinātniskās konferences rakstu krājums. Rīga: LU Akadēmiskais apgāds, 2018, 31.-39. lpp.

7. Latvijas Republikas Civillikuma komentāri: Ceturtā daḷa. Saistību tiesības. K. Torgāns (zin. red.). Riga: Mans īpašums, 1998.

8. Repšs A. Uzṇēmuma pāreja citai personai un darbinieku tiesību aizsardzība. Jurista Vārds. 2004. 9. marts, Nr. 9 (314).

9. Thompson R. B. Piercing the Corporate Veil: An Empirical Study. Cornell Law Review. Volume 76, 1991, 5 July, pp. 1036-1074.

10. Strupišs A. Komerclikuma komentāri. a daḷa. Komercdarbības vispārīgie noteikumi (1.73. pants). Rìga: Aigara Strupiša juridiskais birojs, 2003.

11. Strupišs A. Par komerclikuma projektu, nododot to Saeimas izskatīšanai un vispārējai iepazišanai. Pieejams: https://www.vestnesis.lv/ta/id/24539 [aplūkots 2019. gada 15. aprīlī].

12. Strupišs A. Tiesas spriedumu komentāri: par valdes locekli kā darbinieku. Jurista Vārds, 2012. 28. februāris, Nr. 9 (708).

\section{Normativie akti}

13. Eiropas Padomes Direktīva Nr. 2001/23/EK. Oficiālais Vēstnesis L 082, 22/03/2001, 0016.0020. lpp.

14. Maksātnespējas likums. LV Likums. Latvijas Vēstnesis. 2010. 6. augusts, Nr. 124.

15. Darba likums. LV Likums. Latvijas Vēstnesis. 2001. 6. jūlijs, Nr. 105.

16. Komerclikums. LV Likums. Latvijas Vēstnesis. 2000. 4. maijs, Nr. 158/160.

17. Koncernu likums. LV Likums. Latvijas Vēstnesis. 2000. 13. aprīlis, Nr. 131/132.

18. Civilprocesa likums. LV Likums. Latvijas Vēstnesis. 1998. 3. novembris, Nr. 326/330.

19. Civillikums. LV Likums. Valdības Vēstnesis. 1937. 20. februāris, Nr. 41.

\section{Juridiskās prakses materiāli}

20. Eiropas Savienības Tiesas spriedums lietā Nr. C-175/99 Didier Mayeur v. Associtation Promotion de l'information messine. Sk. arī Eiropas Savienības Tiesas spriedumu lietā Nr. C-13/95 Süzen v. Zehnacker Gebäudereinigung.

21. Eiropas Savienības Tiesas apvienotās lietas C-171/94 un C-172/94 Merckx v. Ford Motor Company and Neuhuys [1996] ECR, p. I-1253. 
22. Eiropas Savienības Tiesas 1986. gada 18. marta spriedums lietā Nr. 24/85 Jozef Maria Antonius Spijkers $v$ Gebroeders Benedik Abattoir CV and Alfred Benedik en Zonen BV.

23. Eiropas Savienības Tiesas 1988. gada 15. jūnija spriedums lietā Nr. 101/97 Bork International $A / S$, in liquidation $v$ Foreningen of Arbejdsledere I Danmark, acting on behalf of Birger E. Petersen, ECR, 1988.

24. Eiropas Savienības Tiesas 1992. gada 19. maija spriedums lietā Nr. C-29/91 Dr. Sophie Redmond Stichting $v$ Hendrikus Bartol and others, ECR 1992.

25. Eiropas Savienības Tiesas 1992. gada 16. decembra spriedums apvienotajās lietās Nr. C-132/91, C-138/91 un C-139/91 Grigorios Katsikas v Angelos Konstantidis and Uwe Skreb and Günter Schroll v PCO Stauereibetrieb Paetz \& Co Nachfolger GmbH.

26. Latvijas Republikas Augstākās tiesas Senāta 2019. gada 30. maija spriedums lietā Nr. SKC104/2019.

27. Latvijas Republikas Augstākās tiesas Senāta 2019. gada 24. aprīḷa spriedums lietā Nr. SKC-46/2019.

28. Latvijas Republikas Augstākās tiesas Civillietu departamenta 2017. gada 15. decembra spriedums lietā Nr. SKC-330/2017.

29. Latvijas Republikas Augstākā tiesas Civillietu departamenta 2017. gada 14. decembra lietā Nr. SKC-265/2017.

30. Latvijas Republikas Augstākās tiesas Civillietu departamenta 2017. gada 9. novembra spriedums lietā Nr. SKC-340/2017.

31. Latvijas Republikas Augstākās tiesas Civillietu departamenta 2017. gada 15. jūnija SKC-108/2017.

32. Latvijas Republikas Augstākās tiesas Civillietu tiesu palātas 2013. gada 5. novembra spriedums lietā Nr. C04367311.

33. Latvijas Republikas Administratīvā rajona tiesas 2013. gada 27. augusta spriedums lietā Nr. A420509512.

34. Latvijas Republikas Augstākās tiesas Senāta 2007. gada 14. marta spriedums lietā Nr. SKC-134. 